\title{
Proceeding
}

Supplementary Issue: Spring Conferences of Sports Science. 15th Convention and Workshop of the International Network of Sport and Health Science, 5-8 June 2019. University of Las Palmas de Gran Canaria, Las Palmas de Gran Canaria, Spain.

\section{Comparison of the seventeen Italian master's degree courses in sports sciences}

\author{
ILARIA SANSEVIERO ${ }^{1}$, SIMONA FATTORE ${ }^{1}$, SALVATORE PIGNATO², FRANCESCA D'ELIA ${ }^{1}$ \\ 1 University of Salerno, Italy \\ 2University Kore of Enna, Italy
}

\begin{abstract}
In Italy, degree courses in Sports Sciences were born in 2001, first in didactic organization of the old system, then specialistic courses were added and, finally, only in 2007 master's degree courses took place. Originally born only in a few locations, these degree courses have progressively developed throughout national territory. They are three different types: -Management of sport and motor activities (LM-47); - Sciences and Techniques of Preventive and Adapted Motor Activities (LM-67); - Sports Sciences and Techniques (LM-68). In the previous study, "Preliminary study on the master's degree in sciences of Sports Evaluation and Sport for disabled at University of Salerno", was analysed the development, over last four years, of study plans and educational objectives exclusively of the LM-68 course of Salerno's University. The objective of this new study is to analyse Professional Profile, Istat Codes and Student's Opinion, to see if the specific educational objectives of all 17 Italian master's degree courses in Sport Science and Techniques are consistent with each other. In this way we could check if there could be improvements. The method used for this second survey is the archive research, with an official documentary analysis and with references to the statistical surveys extrapolated from AlmaLaurea consortium. Results appear extremely heterogeneous due to the total university autonomy, but this doesn't help cooperation, despite the law prescribes obligations to bring out uniformity. Therefore, coordination actions are considered appropriate to make the training more uniform than the current one. Keywords: Training; Uniformity; Graduation; Survey; Comparison; Sport.
\end{abstract}

\section{Cite this article as:}

Sanseviero, I., Fattore, S., Pignato, S., \& D'Elia, F. (2019). Comparison of the seventeen Italian master's degree courses in sports sciences. Journal of Human Sport and Exercise, 14(4proc), S670-S685. doi:https://doi.org/10.14198/ihse.2019.14.Proc4.27

Corresponding author. University of Salerno, Italy.

E-mail: ilariasanseviero@gmail.com

Supplementary Issue: Spring Conferences of Sports Science. 15th Convention and Workshop of the International Network of Sport and Health Science, 5-8 June 2019. University of Las Palmas de Gran Canaria, Las Palmas de Gran Canaria, Spain. JOURNAL OF HUMAN SPORT \& EXERCISE ISSN 1988-5202

(c) Faculty of Education. University of Alicante doi:10.14198/jhse.2019.14.Proc4.27 


\section{INTRODUCTION}

In Italian universities, master degree courses in Sport Science (D'Elia, 2019, D'Isanto, 2019, D'elia et al, 2018, began to develop in 2001 according to generalized scientific paradigm of exercise and sport sciences (Ceciliani, 2019, Ceciliani et al, 2005, Di Tore et al, 2016, D'Isanto 2016, Raiola, 2017, Cassese, Raiola, 2018, Valentini et al, 2018ab), initially with an old-style didactic organization; then the specialist degree courses were added and, finally, only in 2007 the current master degree courses were held. Initially born only in a few locations, these degree courses have progressively developed throughout the national territory. This is due to increasing levels of physical inactivity and probably also to the availability of high-calorie food that is leading an increasing number of people to develop pathological conditions. These courses aim to promote lifestyle changes to maintain acceptable levels of physical activity and to ensure long-term psychological and physical well-being, in relation to possibilities and age, in order to produce benefits for all, in terms of learning, participation, inclusion (Pisapia, D'Isanto, 2018, Raiola, 2015ab) and health (Tiziana, et al, 2017 Gaetano, 2016). Actually, before describing the degree courses currently in force in Italy, it is good to make a premise: the Italian academic disciplines are structured in an atypical way compared to those of other European countries. In fact, the case of physical activity and sports sciences implements a typically Italian solution that sees the division into two different scientific areas with opposite traditions and research methods: a didacticeducational part, in an area defined as non-bibliometric area, and a biomedical part, located in a bibliometric area, both for the evaluation of scientific products. This causes difficulties in evaluating not only of the research, but also and above all of the training and the didactic organization (Raiola, G., D'elia, F., Altavilla, G., 2018). It is important to underline this in order to understand, and probably justify, the discrepancies between the different courses in Italy.

Currently there are three different types of master's degree in sports sciences: - Management of Sport and motor activities (LM-47); - Sciences and Techniques of Preventive and Adapted Motor Activities (LM-67); Sports Sciences and Techniques (LM-68). In the previous study, "Preliminary study on the master's degree in sciences of Sports Evaluation and Sport for disabled at the University of Salerno", the development, in the last four years, of the study plans and the educational objectives exclusively of the LM-68 course was analysed (Sanseviero, I., et al., 2019). Now, the aim of this new study is to analyse the professional profile, the Istat Codes and the Student Opinion in the 17 master's degree courses in Sport Sciences and Techniques active in Italy, to verify if the specific educational objectives are consistent between them. In this way we can check if there may be improvements.

\section{METHOD}

As already mentioned above, following the analysis of the single University of Salerno, an analysis of the degree course LM - 68 was carried out in the various Italian universities. For this research, the Universitaly.it site was used, the portal of the Ministry of Education, University and Research, created specifically to accompany students in their studies. A dedicated section of the site allows to enter the world of Italian degree courses and here each university can propose its educational offer in a clear and functional way. The universities in which this course of study is present are 17, also taking into consideration the University of Salerno. Therefore, the method used for this second investigation was the archive search, with an official documental analysis and with references to the statistical surveys extrapolated by the AlmaLaurea consortium. Specifically, to carry out this new analysis, the Annual Single Cards of each Study Program (SUA-CdS) were consulted, the instrument through which each university expresses the objectives that it proposes to achieve, and in particular the research has focused on four parameters: 1. Professional profile; 2. Istat Codes; 3 . Training objectives; 4 . Opinion of students and graduates. 


\section{RESULT}

The extrapolated results, to ensure greater clarity, were divided into two separate summary tables: in table no. 1 there is the professional profile to which the degree course prepares, the Istat codes that define the profession and the opinion of the students and of graduates; in table no. 2, instead, the educational objectives are summarized, and therefore the skills and competences, which each university intends to achieve for the students enrolled in the degree course analysed. Moreover, the additional explanatory table no. 3 has been added which specifies which university prepares for a specific profession (codified by ISTAT).

Table 1. ISTAT codes and student and graduate opinions of Italian universities

\begin{tabular}{|c|c|c|c|}
\hline University & Professional profile & $\begin{array}{l}\text { ISTAT CODES: } \\
\text { The course prepares } \\
\text { for the profession of }\end{array}$ & $\begin{array}{l}\text { Opinions of students and } \\
\text { graduates }\end{array}$ \\
\hline $\begin{array}{l}\text { BARI - } \\
\text { Sports } \\
\text { sciences and } \\
\text { techniques }\end{array}$ & $\begin{array}{l}\text { Master's Degree in } \\
\text { Sport Sciences and } \\
\text { Techniques }\end{array}$ & $\begin{array}{l}\text { Nature and sports } \\
\text { guides (3.4.1.5.1); } \\
\text { Instructors of non- } \\
\text { competitive sports } \\
\text { disciplines (3.4.2.4.0); } \\
\text { Event and sports } \\
\text { facilities organizers } \\
(3.4 .2 .5 .1) ; \\
\text { Sports observers } \\
(3.4 .2 .5 .2)\end{array}$ & $\begin{array}{l}\text { STUDENTS OPINION: The most } \\
\text { recent data, relating to the } 2015 / 16 \\
\text { a.y, report an } 89.1 \% \text { satisfaction rate. } \\
\text { GRADUATES OPINION: At the } \\
\text { moment there are no data available. }\end{array}$ \\
\hline $\begin{array}{l}\text { BOLOGNA - } \\
\text { Sports } \\
\text { Activity } \\
\text { Sciences } \\
\text { and } \\
\text { Techniques }\end{array}$ & $\begin{array}{l}\text { Coach and physical } \\
\text { and athletic trainer, } \\
\text { operator in the } \\
\text { recreational activities } \\
\text { preparatory to starting } \\
\text { sport. }\end{array}$ & 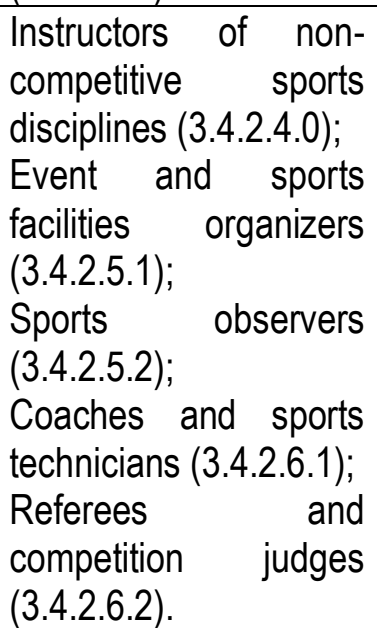 & $\begin{array}{l}\text { STUDENTS OPINION: Data for the } \\
2017 / 18 \text { a.y. show a satisfaction rate } \\
\text { of } 87.92 \% \text {. } \\
\text { GRADUATES OPINION: no data } \\
\text { available. }\end{array}$ \\
\hline $\begin{array}{l}\text { FIRENZE - } \\
\text { interclass } \\
\text { LM-67/ LM- } \\
68 \text { Sports } \\
\text { sciences and } \\
\text { techniques } \\
\text { and of } \\
\text { preventive } \\
\text { and adapted }\end{array}$ & I & $\begin{array}{l}\text { Specialists in education } \\
\text { and training for people } \\
\text { with disabilities } \\
(2.6 .5 .1 .0) \text {; } \\
\text { Instructors of non- } \\
\text { competitive sports } \\
\text { disciplines (3.4.2.4.0); } \\
\text { Coaches and sports } \\
\text { technicians (3.4.2.6.1). }\end{array}$ & $\begin{array}{l}\text { STUDENTS OPINION: } 83.9 \% \text { of } \\
\text { students consider themselves } \\
\text { interested in the subjects and overall } \\
\text { satisfied with the teaching (data } \\
\text { pertaining to the } 17 / 18 \text { a.y.) } \\
\text { GRADUATES OPINION: The data } \\
\text { relating to the } 17 / 18 \text { a.y., updated to } \\
\text { September } 2018 \text {, say that } 21.2 \% \text { of } \\
\text { graduates are satisfied and } 51.5 \%\end{array}$ \\
\hline
\end{tabular}




\begin{tabular}{|c|c|c|c|}
\hline $\begin{array}{l}\text { motor } \\
\text { activities }\end{array}$ & & & $\begin{array}{l}\text { would enrol in the same degree } \\
\text { course ( } 3 \% \text { of the same university). }\end{array}$ \\
\hline $\begin{array}{l}\text { GENOVA - } \\
\text { Sports } \\
\text { sciences and } \\
\text { techniques }\end{array}$ & $\begin{array}{l}\text { The course aims to } \\
\text { train a competent } \\
\text { professional in the field } \\
\text { of sporting activities in } \\
\text { the totality of meanings, } \\
\text { from the recreational, } \\
\text { educational- } \\
\text { recreational, to the } \\
\text { competitive and } \\
\text { organizational- } \\
\text { managerial sphere. }\end{array}$ & $\begin{array}{l}\text { Event and } r \text { sports } \\
\text { facilities organizers } \\
(3.4 .2 .5 .1) ; \\
\text { Sports } \\
(3.4 .2 .5 .2) ; \\
\text { Coaches and } \\
\text { technicians }(3.4 .2 .6 .1) ; \\
\text { Referees } \\
\text { competition } \\
(3.4 .2 .6 .2) .\end{array}$ & $\begin{array}{l}\text { STUDENTS OPINION: } 39.57 \% \text { of } \\
\text { attending students are interested in } \\
\text { the topics covered in the course. } \\
\text { GRADUATES OPINION: } \\
78.6 \% \text { consider themselves satisfied } \\
\text { and would enrol in the same course } \\
\text { and at the same university. }\end{array}$ \\
\hline $\begin{array}{l}\text { L'AQUILA - } \\
\text { Sports } \\
\text { sciences and } \\
\text { techniques }\end{array}$ & $\begin{array}{l}\text { The specific objective is } \\
\text { to provide graduates } \\
\text { with advanced scientific } \\
\text { and methodological } \\
\text { knowledge in the field } \\
\text { of high level sports } \\
\text { activities. }\end{array}$ & $\begin{array}{l}\text { Nature and sports } \\
\text { guides (3.4.1.5.1); } \\
\text { Instructors of } \\
\text { techniques in the } \\
\text { artistic field }(3.4 .2 .3 .0) ; \\
\text { Instructors of non- } \\
\text { competitive sports } \\
\text { disciplines (3.4.2.4.0); } \\
\text { Event and sports } \\
\text { facilities organizers } \\
\text { (3.4.2.5.1); } \\
\text { Sports observers } \\
\text { (3.4.2.5.2); } \\
\text { Coaches and sports } \\
\text { technicians }(3.4 .2 .6 .1) ; \\
\text { Athletes (3.4.2.7.0). }\end{array}$ & No data available \\
\hline $\begin{array}{l}\text { MILANO - } \\
\text { Sports } \\
\text { sciences and } \\
\text { techniques }\end{array}$ & $\begin{array}{l}\text { Expert in training and } \\
\text { physical and technical } \\
\text { preparation in team and } \\
\text { individual sports }\end{array}$ & 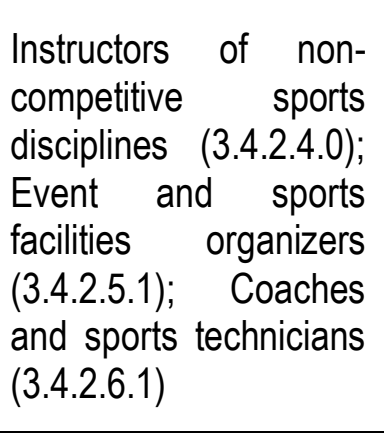 & $\begin{array}{l}\text { STUDENTS OPINION: } 35.4 \% \text { are } \\
\text { overall satisfied with the degree } \\
\text { course and } 87.9 \% \text { would enrol again } \\
\text { in the same course at this university. } \\
\text { GRADUATES } \\
\text { employment rate after } 1 \text { year } 87.5 \% \text {, } \\
\text { after three years } 80.0 \% \text {, after five } \\
\text { years } 100.0 \% \text {. }\end{array}$ \\
\hline $\begin{array}{l}\text { NAPOLI - } \\
\text { LM-47 / LM- } \\
68 \text { : Science } \\
\text { and } \\
\text { Management } \\
\text { of Sport and } \\
\text { Sport } \\
\text { Activities }\end{array}$ & $\begin{array}{l}\text { Manager of companies } \\
\text { operating in the field of } \\
\text { sports activities; } \\
\text { manager in the } \\
\text { management of sports } \\
\text { facilities }\end{array}$ & $\begin{array}{l}\text { Businessmen and } \\
\text { managers of small } \\
\text { businesses in the field } \\
\text { of sports, recreation, } \\
\text { entertainment and } \\
\text { entertainment } \\
(1.3 .1 .9 .3)\end{array}$ & $\begin{array}{l}\text { STUDENTS OPINION: The surveys } \\
\text { carried out show a significant level of } \\
\text { appreciation of the Study Program. } \\
\text { None of the proposed questions was } \\
\text { given a positive rating below } 80 \% \text { with } \\
\text { an average of "decidedly positive" } \\
\text { answers of } 43 \% \text {. } \\
\text { GRADUATES OPINION: Graduates' } \\
\text { satisfaction, according to the Alma }\end{array}$ \\
\hline
\end{tabular}




\begin{tabular}{|c|c|c|c|}
\hline & & & $\begin{array}{l}\text { Aurea } 2017 \text { survey, is: } 37.8 \% \\
\text { (definitely yes). }\end{array}$ \\
\hline $\begin{array}{l}\text { PALERMO- } \\
\text { interclass } \\
\text { LM-67 / LM- } \\
68: \text { Sciences } \\
\text { and } \\
\text { Techniques } \\
\text { of Preventive } \\
\text { and Adapted } \\
\text { Motor } \\
\text { Activities } \\
\text { and Sports } \\
\text { Activities }\end{array}$ & $\begin{array}{l}\text { Technical manager of } \\
\text { facilities where physical } \\
\text { exercise is practiced; } \\
\text { Physical activity } \\
\text { specialist for wellness; } \\
\text { Kinesiologist }\end{array}$ & $\begin{array}{l}\text { Specialists in education } \\
\text { and training for people } \\
\text { with disabilities } \\
(2.6 .5 .1 .0) \text {. }\end{array}$ & $\begin{array}{l}\text { STUDENTS OPINION: } \\
\text { The indicators analysed show an } \\
\text { overall trend that is more than } \\
\text { positive. The quality indexes in } \\
\text { almost all the questions stand above } \\
\text { the value } 8 \text { on a scale from } 1 \text { to } 10 \text {. } \\
\text { GRADUATES OPINION: } \\
\text { The indicators analysed show an } \\
\text { overall trend that is more than } \\
\text { positive. The AlmaLaurea survey } \\
\text { shows a high level of satisfaction with } \\
\text { respect to the University average with } \\
\text { regards to teaching load of courses, } \\
\text { organization of exams, relationship } \\
\text { with teachers, overall satisfaction with } \\
\text { the degree course, evaluation of } \\
\text { classrooms and equipment }\end{array}$ \\
\hline $\begin{array}{l}\text { PAVIA - } \\
\text { Sports } \\
\text { sciences and } \\
\text { techniques }\end{array}$ & $\begin{array}{l}\text { The professional takes } \\
\text { care of the physical } \\
\text { activity from the } \\
\text { technical and sporting } \\
\text { point of view also in the } \\
\text { competitive field }\end{array}$ & $\begin{array}{l}\text { Instructors of non- } \\
\text { competitive } \\
\text { disciplines } \text { sports } \\
\text { Event and sports } \\
\text { facilities organizers } \\
(3.4 .2 .5 .1) ; \quad \text { Coaches } \\
\text { and sports technicians } \\
(3.4 .2 .6 .1) \text {. }\end{array}$ & $\begin{array}{l}\text { STUDENTS OPINION: } \\
\text { / } \\
\text { GRADUATES OPINION: } 41.7 \% \text { are } \\
\text { overall satisfied with the degree } \\
\text { course and } 75 \% \text { would enrol again in } \\
\text { the same degree course at the same } \\
\text { university. The employment rate is } \\
100 \% \text { after one and three years and } \\
50 \% \text { after five years. }\end{array}$ \\
\hline $\begin{array}{l}\text { PERUGIA- } \\
\text { interclass } \\
\text { LM-67/ LM- } \\
68 \text { : Sports } \\
\text { sciences and } \\
\text { techniques } \\
\text { and } \\
\text { preventive } \\
\text { and adapted } \\
\text { motor } \\
\text { activities }\end{array}$ & & $\begin{array}{l}\text { Specialists in education } \\
\text { and training for people } \\
\text { with disabilities } \\
\text { (2.6.5.1.0); } \\
\text { Instructors of non- } \\
\text { competitive sports } \\
\text { disciplines (3.4.2.4.0); } \\
\text { Coaches and sports } \\
\text { technicians (3.4.2.6.1). }\end{array}$ & $\begin{array}{l}\text { STUDENTS OPINION: } 88.8 \% \\
\text { positively evaluate the course and the } \\
\text { teachings. } \\
\text { GRADUATES OPINION: Satisfaction } \\
\text { with the university experience is quite } \\
\text { high, in fact } 78.9 \% \text { of graduates are } \\
\text { satisfied. This satisfaction is also } \\
\text { supported by the fact that } 71.1 \% \text { of } \\
\text { the students would rewrite the same } \\
\text { master's course at the same } \\
\text { university }\end{array}$ \\
\hline $\begin{array}{l}\text { ROMA "Foro } \\
\text { Italico" - } \\
\text { Sports } \\
\text { sciences and } \\
\text { techniques }\end{array}$ & $\begin{array}{lr}\text { Instructors of } & \text { non- } \\
\text { competitive } & \text { sports } \\
\text { disciplines, Event and } \\
\text { sports } & \text { facilities } \\
\text { organizers, } & \text { Sports } \\
\text { observers, } & \text { Coaches } \\
\text { and sports technicians, }\end{array}$ & $\begin{array}{l}\text { Instructors of non- } \\
\text { competitive sports } \\
\text { disciplines }(3.4 .2 .4 .0) ; \\
\text { Event and sports } \\
\text { facilities organizers } \\
(3.4 .2 .5 .1) ;\end{array}$ & $\begin{array}{l}\text { STUDENTS OPINION: The analysis } \\
\text { shows an assessment with a total } \\
\text { average IVP of } 88.4 \% \text {. Therefore, the } \\
\text { effective overall organization of the } \\
\text { LM- } 68 \text { courses in line with the } \\
\text { educational objectives and the }\end{array}$ \\
\hline
\end{tabular}




\begin{tabular}{|c|c|c|c|}
\hline & $\begin{array}{l}\text { Referees and } \\
\text { competition judges }\end{array}$ & $\begin{array}{l}\text { Sports observers } \\
(3.4 .2 .5 .2) ; \\
\text { Coaches and sports } \\
\text { technicians }(3.4 .2 .6 .1) ; \\
\text { Referees and } \\
\text { competition judges } \\
(3.4 .2 .6 .2) .\end{array}$ & $\begin{array}{l}\text { general satisfaction of the students } \\
\text { are confirmed. } \\
\text { GRADUATES OPINION: The } \\
\text { analysis confirms: } \\
\text { - a satisfactory employment outcome } \\
\text { of } 1(88 \%), 3(91 \%) \text { and } 5(96 \%) \\
\text { years from graduation; } \\
\text { - a high degree of satisfaction with the } \\
\text { degree course ( } 81 \%) \text {; } \\
\text { - the number of graduates who would } \\
\text { enrol again in the same degree } \\
\text { course at the same university is over } \\
85 \% \text {. }\end{array}$ \\
\hline $\begin{array}{l}\text { ROMA "Tor } \\
\text { Vergata"- } \\
\text { Sports } \\
\text { sciences and } \\
\text { techniques }\end{array}$ & $\begin{array}{l}\text { Highly qualified } \\
\text { professional figures } \\
\text { who can work in the } \\
\text { world of fitness and } \\
\text { wellness }\end{array}$ & $\begin{array}{l}\text { Instructors of non- } \\
\text { competitive } \\
\text { disciplines }(3.4 .2 .4 .0) ; \\
\text { Event and sports } \\
\text { facilities organizers } \\
(3.4 .2 .5 .1) ; \\
\text { Sports observers } \\
(3.4 .2 .5 .2) .\end{array}$ & $\begin{array}{l}\text { STUDENTS OPINION: The } \\
\text { representation of the average } \\
\text { valuations obtained highlights the } \\
\text { concentration of positive judgments. } \\
\text { GRADUATES OPINION: Over } 90 \% \\
\text { of graduates express an overall } \\
\text { satisfactory judgment of the master's } \\
\text { degree attended and completed. In } \\
\text { particular, over } 78 \% \text { would enrol } \\
\text { again at this university. }\end{array}$ \\
\hline $\begin{array}{l}\text { SALERNO - } \\
\text { Sciences of } \\
\text { Sports } \\
\text { evaluation } \\
\text { and Sport for } \\
\text { disabled }\end{array}$ & $\begin{array}{l}\text { Expert in } \\
\text { sciences } \\
\text { techniques }\end{array}$ & $\begin{array}{l}\text { Instructors of non- } \\
\text { competitive } \\
\text { disciplines } \text { sports } \\
\text { Event and } 3.4 .2 .4 .0) \text {; } \\
\text { facilities } \\
(3.4 .2 .5 .1) ; \quad \text { Coachers } \\
\text { and sports technicians } \\
(3.4 .2 .6 .1) .\end{array}$ & $\begin{array}{l}\text { STUDENTS OPINION: } 89.14 \% \text { of } \\
\text { attending students and } 81.27 \% \text { of } \\
\text { non-attending students are interested } \\
\text { in the subjects taught. } \\
\text { GRADUATES OPINION: } \\
83 \% \text { would enrol in the same course } \\
\text { at the same university. The } \\
\text { employment rate is } 60 \% \text { one year } \\
\text { after graduation, } 66.7 \% \text { after three } \\
\text { years and } 73.3 \% \text { after five years. }\end{array}$ \\
\hline $\begin{array}{l}\text { TORINO - } \\
\text { Advanced } \\
\text { sports } \\
\text { sciences and } \\
\text { techniques }\end{array}$ & $\begin{array}{l}\text { Coaches and sports } \\
\text { technicians; } \\
\text { Technical text editors; } \\
\text { Sports observers; } \\
\text { kinesiologists }\end{array}$ & $\begin{array}{l}\text { Technical text editors } \\
(2.5 .4 .1 .4) ; \\
\text { Specialists in education } \\
\text { and training for people } \\
\text { with disabilities } \\
(2.6 .5 .1 .0) ; \\
\text { Event and sports } \\
\text { facilities organizers } \\
(3.4 .2 .5 .1) ; \\
\text { Sports observers } \\
(3.4 .2 .5 .2) ;\end{array}$ & $\begin{array}{l}\text { STUDENTS OPINION: from the data } \\
\text { it emerges that all the satisfaction } \\
\text { indicators are positive with the } \\
\text { exception of the entry concerning the } \\
\text { classrooms. } \\
\text { GRADUATES OPINION: The } \\
\text { assessments are totally positive (> } \\
80 \% \text { ) on the course, on the study load } \\
\text { and less on the structures (in this } \\
\text { case } 50 \% \text { are never reached for } \\
\text { classrooms, libraries and study }\end{array}$ \\
\hline
\end{tabular}




\begin{tabular}{|c|c|c|c|}
\hline & & $\begin{array}{l}\text { Coaches and sports } \\
\text { technicians }(3.4 .2 .6 .1) ; \\
\text { Referees and } \\
\text { competition judges } \\
(3.4 .2 .6 .2) .\end{array}$ & $\begin{array}{l}\text { rooms). More than } 74 \% \text { of } \\
\text { respondents would repeat the same } \\
\text { choice in the same university. }\end{array}$ \\
\hline $\begin{array}{l}\text { UDINE - } \\
\text { Sport } \\
\text { sciences }\end{array}$ & I & $\begin{array}{l}\text { Event and sports } \\
\text { facilities organizers } \\
(3.4 .2 .5 .1) ; \\
\text { Sports observers } \\
(3.4 .2 .5 .2) ; \\
\text { Coaches and sports } \\
\text { technicians }(3.4 .2 .6 .1) ; \\
\text { Referees and } \\
\text { competition judges } \\
(3.4 .2 .6 .2) .\end{array}$ & $\begin{array}{l}\text { STUDENTS OPINION: } 45.1 \% \text { of } \\
\text { students (attending or not) are } \\
\text { satisfied with the teaching. } \\
\text { GRADUATES OPINION: } 75 \% \text { would } \\
\text { enrol in the same course at the same } \\
\text { university. } \\
\text { The employment rate is } 50.0 \% \text { after } \\
\text { one year, } 100.0 \% \text { after three years } \\
\text { and } 60.0 \% \text { after five years. }\end{array}$ \\
\hline $\begin{array}{l}\text { Urbino - } \\
\text { Sports } \\
\text { sciences }\end{array}$ & $\begin{array}{l}\text { Event and sports } \\
\text { facilities organizers; } \\
\text { coaches and sports } \\
\text { technicians. }\end{array}$ & $\begin{array}{l}\text { Event and sports } \\
\text { facilities organizers } \\
(3.4 .2 .5 .1) \text {; } \\
\text { Coaches and sports } \\
\text { technicians }(3.4 .2 .6 .1)\end{array}$ & $\begin{array}{l}\text { STUDENTS OPINION: } \\
\text { Attending students show a good } \\
\text { degree of satisfaction (on average } \\
\text { around } 87 \% \text { of positive answers). } \\
\text { GRADUATES OPINION: } \\
90.6 \% \text { of students are satisfied. }\end{array}$ \\
\hline $\begin{array}{l}\text { VERONA - } \\
\text { Sports and } \\
\text { physical } \\
\text { performance } \\
\text { sciences }\end{array}$ & $\begin{array}{l}\text { Expert in amateur and } \\
\text { competitive sports. }\end{array}$ & $\begin{array}{l}\text { Instructors of non- } \\
\text { competitive sports } \\
\text { disciplines }(3.4 .2 .4 .0) ; \\
\text { Event and sports } \\
\text { facilities organizers } \\
(3.4 .2 .5 .1) ; \\
\text { Sports observers } \\
(3.4 .2 .5 .2) ; \\
\text { Coaches and sports } \\
\text { technicians }(3.4 .2 .6 .1)\end{array}$ & $\begin{array}{l}\text { STUDENT OPINION: Overall, } \\
24.09 \% \text { are satisfied with how the } \\
\text { teaching was carried out. } \\
\text { GRADUATES OPINION: } 36 \% \text { are } \\
\text { satisfied with the course of study and } \\
74.4 \% \text { would enrol in the same } \\
\text { course at the same university. }\end{array}$ \\
\hline
\end{tabular}

Table 2. Description of training objectives of Italian universities

\begin{tabular}{|l|l|}
\hline $\begin{array}{l}\text { University and } \\
\text { course of study }\end{array}$ & Description of training objectives: \\
\hline & $\begin{array}{l}\text { The course intends to achieve the objectives through the achievement of cultural, } \\
\text { instrumental and methodological learning in the various disciplinary/cultural areas } \\
\text { that form and complete the training course in sports sciences and techniques. } \\
\text { These training objectives include knowing the principles of research and teaching } \\
\text { applicable to the numerous sports disciplines; to be able to operate as qualified } \\
\text { professional figures in the field of sports clubs and any other sports context, with } \\
\text { roles also of an organizational type, as well as technical-scientific, capable of } \\
\text { formulating sports educational paths for the individual age groups and for each } \\
\text { sciences and } \\
\text { techniques }\end{array}$ \\
$\begin{array}{l}\text { level of competence expressed and competitive level; to know and being able to } \\
\text { use the principles of bio-medical and psychological disciplines to achieve sports } \\
\text { and educational results while respecting the psychophysical balance of the }\end{array}$ \\
\hline
\end{tabular}




\begin{tabular}{|c|c|}
\hline & $\begin{array}{l}\text { practitioner; to acquire specific knowledge about sports education that can be used } \\
\text { in formal (school-education) and informal (training, social contexts, etc.) training } \\
\text { systems. }\end{array}$ \\
\hline $\begin{array}{l}\text { BOLOGNA - Sports } \\
\text { Activity Sciences } \\
\text { and Techniques }\end{array}$ & $\begin{array}{l}\text { The goal is to provide graduates with advanced scientific knowledge in the field of } \\
\text { high level sports activities. In the Course, knowledge and skills are acquired to } \\
\text { induce athletes to achieve the best competitive performance through advanced } \\
\text { training techniques and to optimize the physiological and technical performance of } \\
\text { the athlete. }\end{array}$ \\
\hline $\begin{array}{l}\text { FIRENZE - } \\
\text { interclass LM-67/ } \\
\text { LM-68 Sports } \\
\text { sciences and } \\
\text { techniques and of } \\
\text { preventive and } \\
\text { adapted motor } \\
\text { activities }\end{array}$ & $\begin{array}{l}\text { Graduates of this class must be able to know fundamental elements of } \\
\text { biomechanics to deepen their knowledge of the fundamental technical gestures of } \\
\text { the various sports disciplines; know the methods for learning and cognitive training } \\
\text { for the construction and training of individual and team tactical thinking, knowing } \\
\text { the basic elements of human physiology to implement training methods to plan } \\
\text { annual/multi-year plans and cycles training for advanced and youth teams; know } \\
\text { and master functional anatomical knowledge to prepare post-traumatic recovery } \\
\text { plans; know means and methods to identify wellness paths to operate in private } \\
\text { structures. They must know the fundamentals of the psychological management } \\
\text { of society organizations, they must have planning bases for the structuring of } \\
\text { projects and interventions. They must have basic notions and normative } \\
\text { references regarding the health promotion of athletes and athletes, with particular } \\
\text { attention to nutrition, nutrition hygiene and doping regulations; learn the basics of } \\
\text { sports medicine and traumatology. They will need to have a basic knowledge of } \\
\text { the rules and general concepts of labour law, applied to the sports sector. }\end{array}$ \\
\hline $\begin{array}{l}\text { GENOVA - Sports } \\
\text { sciences and } \\
\text { techniques }\end{array}$ & $\begin{array}{l}\text { The goal is to provide graduates with advanced scientific knowledge in the field of } \\
\text { high level sports activities. In the course are acquired: knowledge related to the } \\
\text { optimization of the physiological and technical performance of the athlete; } \\
\text { knowledge and skills aimed at achieving the best competitive performance through } \\
\text { advanced training techniques; knowledge on the organization, coordination, } \\
\text { management and management of sporting events. }\end{array}$ \\
\hline $\begin{array}{l}\text { L'AQUILA - Sports } \\
\text { sciences and } \\
\text { techniques }\end{array}$ & $\begin{array}{l}\text { The specific objective is to provide graduates with advanced scientific and } \\
\text { methodological knowledge in the field of high level sports activities. The course } \\
\text { acquires knowledge and skills to help athletes achieve optimal performance } \\
\text { through advanced training techniques and to optimize the physiological and } \\
\text { technical performance of the athlete. The course is divided into two distinct } \\
\text { curricula, the first oriented to the training and assessment methodology, the } \\
\text { second to the physical preparation and management of physical and sports } \\
\text { activities in the mountains. }\end{array}$ \\
\hline $\begin{array}{l}\text { MILANO - Sports } \\
\text { sciences and } \\
\text { techniques }\end{array}$ & $\begin{array}{l}\text { The course aims to prepare graduates with extensive skills in the elite sports sector } \\
\text { and sport for all. In particular it will provide the knowledge and skills suitable for the } \\
\text { implementation and innovation of sports activities aimed at different ages, with } \\
\text { particular reference to high level sports, in relation to the didactic, methodological } \\
\text { and technical aspects of the various disciplines. The training course also includes } \\
\text { theoretical and methodological skills aimed at the correct management of the } \\
\text { lifestyle of the sportsman. Graduates will also have management skills to deal with } \\
\text { the preparation, coordination and management of sporting events. In the first year } \\
\text { the course provides the fundamental elements of specialization, in particular of a } \\
\text { biomedical nature, as well as the specific theoretical and practical preparation of }\end{array}$ \\
\hline
\end{tabular}




\begin{tabular}{|c|c|}
\hline & $\begin{array}{l}\text { the training methodology and the functional evaluation of athletes. The in-depth } \\
\text { analysis of the techniques and methodologies applicable to different sports } \\
\text { activities is also provided. The second year is mainly intended for periods of } \\
\text { training internships at sports centres, gyms, facilities, specially affiliated } \\
\text { educational institutions and possible study stays at other foreign universities. The } \\
\text { training can be directed both towards specific technical and didactic competences } \\
\text { of the sports field, and towards a more specifically specific orientation to the } \\
\text { teaching of physical education in the school environment. }\end{array}$ \\
\hline $\begin{array}{l}\text { NAPOLI -LM-47 / } \\
\text { LM-68 : Science and } \\
\text { Management of } \\
\text { Sport and Sport } \\
\text { Activities }\end{array}$ & $\begin{array}{l}\text { Graduates will have an interdisciplinary preparation integrating both the issues of } \\
\text { management and the organization of sports societies and those concerning } \\
\text { training both at an amateur level for wellness purposes and at a competitive level. } \\
\text { In particular, they will have: specific skills relating to the organization and } \\
\text { management of physical and sports activities and the systems dedicated to them; } \\
\text { advanced knowledge about the institutional structures within which the sports } \\
\text { activities system is placed, with particular attention to the anti-doping legislation; } \\
\text { knowledge on the organization, coordination, management and management of } \\
\text { sporting events; competences regarding the economic management of sports and } \\
\text { health-related companies; advanced scientific knowledge in the field of high level } \\
\text { sports activities; knowledge and skills aimed at achieving the best competitive } \\
\text { performance using advanced training techniques. }\end{array}$ \\
\hline $\begin{array}{l}\text { PALERMO- } \\
\text { interclass LM-67 / } \\
\text { LM-68: Sciences } \\
\text { and Techniques of } \\
\text { Preventive and } \\
\text { Adapted Motor } \\
\text { Activities and Sports } \\
\text { Activities }\end{array}$ & $\begin{array}{l}\text { The basic objective of the course is to provide graduates with advanced scientific } \\
\text { knowledge in the field of human motor activities, with particular regard to } \\
\text { preventive and adaptive areas. In the Course knowledge is acquired for the } \\
\text { maintenance of the best physical efficiency both in normal subjects and in } \\
\text { populations predisposed or affected by pathologies correlated with a sedentary } \\
\text { lifestyle, or with incorrect lifestyles, adapting motor activities also to the needs of } \\
\text { subjects with motor disabilities, or suffering from diseases that can benefit from } \\
\text { physical exercise, including the acquisition of skills aimed at prevention and } \\
\text { recovery, through physical activity, from situations of child and adolescent distress. } \\
\text { The course will also acquire knowledge and skills to induce in athletes the } \\
\text { optimization of physiological and technical performance in order to achieve the } \\
\text { best competitive performance through advanced training techniques. Particular } \\
\text { attention will be paid to the evaluation of the athlete and to the planning and } \\
\text { conduct of basic scientific research applied to sport. In particular, technical- } \\
\text { practical field demonstrations and individual exercises with the use of advanced } \\
\text { performance analysis tools are foreseen. }\end{array}$ \\
\hline $\begin{array}{l}\text { PAVIA - Sports } \\
\text { sciences and } \\
\text { techniques }\end{array}$ & $\begin{array}{l}\text { The general objective is to acquire advanced scientific knowledge in the field of } \\
\text { human motor activities, with particular regard to the technical-sporting area. } \\
\text { Knowledge and skills will be acquired to plan, conduct, manage and control sports } \\
\text { activities, both amateur and competitive, and knowledge and skills for teaching } \\
\text { motor and sports activities. In particular, specific training objectives of the course } \\
\text { will be: - to reach advanced level competences on the theoretical, methodological } \\
\text { and technical bases of training in individual and team sports disciplines; - know } \\
\text { methods and measuring instruments for the evaluation of sports practice also for } \\
\text { the purpose of technical advice and testing in relation to the goods and services } \\
\text { used; - know the methods of assessment of physical and sporting performance, } \\
\text { know how to use them and evaluate their results in a quantitative manner relative }\end{array}$ \\
\hline
\end{tabular}




\begin{tabular}{|c|c|}
\hline & $\begin{array}{l}\text { to the various disciplines, in the context of gender, age and the objectives of sports; } \\
\text { - know the institutional arrangements within which the sports activities system is } \\
\text { placed; - know the problems concerning the processes and methods of learning } \\
\text { and teaching, the characteristics of cognitive, emotional and personal development } \\
\text { in adolescence; - acquire the teaching methods referring to the areas of the } \\
\text { disciplinary structure related to physical activity; - design, propose and manage } \\
\text { pathways and protocols of physical activity in children and adolescents. } \\
\text { Furthermore, the acquisition of specific methodological, technological and } \\
\text { experimental skills will be guaranteed, with reference to the design and } \\
\text { development of devices for motor analysis, to quantitative analysis of the } \\
\text { movement and to the evaluation of the athletic gesture in the sportsman for the } \\
\text { optimization of results. }\end{array}$ \\
\hline $\begin{array}{l}\text { PERUGIA- LM-67/ } \\
\text { LM-68 interclass } \\
\text { Sports sciences and } \\
\text { techniques and } \\
\text { preventive and } \\
\text { adapted motor } \\
\text { activities }\end{array}$ & $\begin{array}{l}\text { The Interclass Degree Course was established to meet the modern needs of high } \\
\text { professionalization in the field of motor and sports activities. For this reason the } \\
\text { continuous mutation of the concept of health has been taken into strong } \\
\text { consideration, which today is based strictly on the concept of the person starting } \\
\text { from the prevention plan up to the interaction with the environment. All this } \\
\text { constitutes that process of prevention-diagnosis-cure-re-education that requires } \\
\text { specific interdisciplinary knowledge regarding both motor and sports activities and } \\
\text { prevention. A unified course has therefore been created that can ensure a common } \\
\text { path differentiated only by specific distinctive areas that highlights competent } \\
\text { professional figures and able to meet a specific and professionalizing demand of } \\
\text { the labour market. The training course aims to provide learners with knowledge } \\
\text { and skills suitable for the proposal and implementation of methodological } \\
\text { innovation in the field of motor and sports activities aimed at different ages of life } \\
\text { and people suffering from physical and mental pathologies congenital or acquired, } \\
\text { chronic course and impact on the ability to participate in society. The course will } \\
\text { be articulated in such a way as to allow the students to acquire the necessary and } \\
\text { specific skills common to motor and sports activities through the study of } \\
\text { anatomical, biomechanical, methodological, socio-pedagogical and medical } \\
\text { mechanisms. }\end{array}$ \\
\hline $\begin{array}{l}\text { ROMA "Foro } \\
\text { Italico"- Sports } \\
\text { sciences and } \\
\text { techniques }\end{array}$ & $\begin{array}{l}\text { The degree course offers a training whose contents are strongly oriented towards } \\
\text { competitive sport and related professions. It offers a training course that will allow, } \\
\text { on the one hand, to prepare fully qualified professionals to operate at medium-high } \\
\text { levels in the world of competitive sport up to the elite and, on the other hand, to } \\
\text { form the leverage of new aspiring researchers ready to access doctoral courses. } \\
\text { For this reason, the planned training activities must provide a solid preparation, } \\
\text { especially in the technical-sporting, biological, medical, psychological and } \\
\text { pedagogical fields, with elements of legal knowledge. The course of study will } \\
\text { provide the ability to guide the athlete from an early age to his evolution into a } \\
\text { mature athlete through the knowledge of the: -Scientific bases and methodologies } \\
\text { of design, conduction, prescription and management of technical-tactical training, } \\
\text { and of physical preparation in different sports disciplines; - Methodologies and } \\
\text { techniques for the functional and sporting evaluation of the athlete, his aptitude } \\
\text { and sporting talent, for a correct design and individualized planning of the training } \\
\text { process; -Knowledge of biomedical and psycho-pedagogical aspects related to } \\
\text { sports activities, to the protection and recovery of the athlete's health and }\end{array}$ \\
\hline
\end{tabular}




\begin{tabular}{|c|c|}
\hline & $\begin{array}{l}\text { performance, to the diffusion of correct behaviour in the field of health and hygiene, } \\
\text { and to the right of citizenship in sport and to the more general processes of } \\
\text { inclusion. Internship activities and various practical activities will take on a } \\
\text { predominant role in the structure of the training offer. }\end{array}$ \\
\hline $\begin{array}{l}\text { ROMA "Tor } \\
\text { Vergata"- Sports } \\
\text { sciences and } \\
\text { techniques }\end{array}$ & $\begin{array}{l}\text { Graduates must be able to use advanced cultural, methodological and technical- } \\
\text { practical tools with particular reference to: Design, coordination and technical } \\
\text { direction of personalized physical preparation activities and technical sports } \\
\text { activities at various levels, at sports associations and societies, sports promotion } \\
\text { bodies, institutions and specialized centres; Design, coordination and technical } \\
\text { direction of customized physical preparation activities for the elderly and disabled; } \\
\text { Physical preparation and personalized technique aimed at individual and team } \\
\text { preparation. Graduates must have specific and in-depth skills in the field of motor } \\
\text { and sports activities with attention to different types of disciplines and differences } \\
\text { related to age, gender, socio-cultural context of belonging, the level of psycho- } \\
\text { cultural maturity and the presence of physical disabilities. }\end{array}$ \\
\hline $\begin{array}{l}\text { SALERNO - } \\
\text { Sciences of Sports } \\
\text { evaluation and Sport } \\
\text { for disabled }\end{array}$ & $\begin{array}{l}\text { The Course declines the objectives and knowledge in the different contexts of } \\
\text { motor and sports practice, from the socio-educational and school environment to } \\
\text { professional, amateur and amateur sports, orienting the training course in } \\
\text { particular on the processes of analysis, evaluation and planning of movement and } \\
\text { sport in an inclusive perspective. The training contents and objectives of the course } \\
\text { are referable to training activities that contribute to specific learning of: humanistic } \\
\text { area, aimed at defining the socio-psycho-pedagogical and didactic basis of } \\
\text { educational practices and inclusive embodied, of the main models and methods of } \\
\text { research centred on the body in motion, of educational design through and towards } \\
\text { movement and sport, of the sport-society relationship, of the cultural definition of } \\
\text { concepts related to sport and well-being; motor area, aimed at providing theoretical } \\
\text { and methodological tools for the design, coordination and teaching of motor } \\
\text { activities in socio-educational contexts with specificity of gender, age and presence } \\
\text { of disabilities and the evaluation of the psychomotor components of action and the } \\
\text { deepening of the methods and tools of biomechanical analysis and evaluation of } \\
\text { movement for the identification and quantification of patterns characteristic of } \\
\text { motor performance in different contexts; sports area, aimed at offering } \\
\text { methodological and technical-practical tools for the design, coordination and } \\
\text { teaching of sports activities in different contexts, as well as methods and tools for } \\
\text { assessing sports performance; biomedical area, aimed at providing the biological } \\
\text { basis of adaptation to physical exercise, knowledge of health risks related to motor } \\
\text { sports practice. }\end{array}$ \\
\hline $\begin{array}{l}\text { TORINO - Advanced } \\
\text { sports sciences and } \\
\text { techniques }\end{array}$ & $\begin{array}{l}\text { Graduates will have to: have a thorough cultural preparation in the area of Sports } \\
\text { and Motor Sciences and be able to design, conduct and manage motor activities, } \\
\text { taking into account any gender specificities; have knowledge of the theoretical, } \\
\text { methodological and technical training in the various disciplines; to know in depth } \\
\text { the most appropriate methodologies and techniques for the functional evaluation } \\
\text { of the athlete, with maximum attention to the protection of his health which must } \\
\text { be preserved from the risks associated with doping activities; to have a specific } \\
\text { competence in the design and management of sports activities for the disabled; to } \\
\text { be able to use the main computer tools in the specific areas of competence; to be } \\
\text { able to work with wide autonomy, also assuming responsibility for projects and }\end{array}$ \\
\hline
\end{tabular}




\begin{tabular}{|c|c|}
\hline & $\begin{array}{l}\text { structures. The course includes training activities aimed at deepening the basic } \\
\text { sports training and its applications in relation to experimental and analytical } \\
\text { methods used in sport, the completion of mathematical, statistical and computer } \\
\text { tools, depending on the technical application; includes training activities aimed at } \\
\text { the acquisition of skills necessary for the implementation of technical and sports } \\
\text { projects with the aim of measuring and assessing the effects of motor and sports } \\
\text { activities of practitioners; provides lessons and exercises, provided as internships, } \\
\text { activated with their own facilities and public and private bodies; provides lessons } \\
\text { and laboratory exercises aimed at the knowledge of tools, methods and protocols } \\
\text { useful for research in sports. }\end{array}$ \\
\hline $\begin{array}{l}\text { UDINE - Sport } \\
\text { sciences }\end{array}$ & $\begin{array}{l}\text { The Course aims to achieve the following objectives: have a solid basic cultural } \\
\text { background and be able to plan, conduct, manage and control motor sports } \\
\text { activities, both amateur and competitive, with particular attention to gender } \\
\text { specificity, to different age groups and to disabled people; have advanced level } \\
\text { skills on the theoretical, methodological and technical foundations of training in } \\
\text { individual and team sports in order to operate in the field of high physical } \\
\text { performance and sports, both in youth and in the absolute sectors, as well as in } \\
\text { the field of sports activities in disabled athletes; have an adequate knowledge of } \\
\text { the aspects inherent in the protection of the health of athletes, with reference also } \\
\text { to the risks associated with the phenomenon of doping; have knowledge and skills } \\
\text { in the pedagogical and psychological field, with reference also to physical and } \\
\text { sporting activity in the disabled; have advanced knowledge about the institutional, } \\
\text { legal and organizational structures within which the system of sports activities is } \\
\text { placed. In addition, as part of the training courses aimed at teaching in secondary } \\
\text { school, graduates must achieve the following objectives: have the pedagogical and } \\
\text { didactic knowledge to choose and master the methods of teaching motor activities } \\
\text { in the context of secondary school activities, including in relation to disabled } \\
\text { students: have the scientific and epistemological knowledge necessary to perform } \\
\text { the function of educator capable of establishing positive and motivating } \\
\text { relationships with students, families and other teachers involved in the educational } \\
\text { process at school level; have the knowledge to promote and organize motor and } \\
\text { sports activities at school. }\end{array}$ \\
\hline $\begin{array}{l}\text { Urbino - Sport } \\
\text { sciences }\end{array}$ & $\begin{array}{l}\text { The training course will ensure the achievement of high competence, through } \\
\text { specific teachings in the fields of biochemistry and physiology of movement and } \\
\text { adaptation to strenuous physical exercise, sports techniques and their teaching, } \\
\text { training methodologies also aimed at top-level competitive sports, methodologies } \\
\text { for measuring and assessing performance, biomechanics, the psychology of the } \\
\text { athlete and groups, the sociological implications of sport, the nutritional needs of } \\
\text { athletes, toxicological risks related to prohibited enhancement practices, such as } \\
\text { doping. The curriculum will ensure the preparation necessary to design and plan } \\
\text { the athletic and technical preparation of the sportsman aimed at competition, while } \\
\text { respecting the health of the individual and the preventive value of sport and motor } \\
\text { activity. The graduate will be able to conduct programs of motor and sports } \\
\text { activities at an individual and group level, interacting with subjects of all ages, } \\
\text { gender, physical and social condition. The attainment of these objectives will be } \\
\text { possible also thanks to a conspicuous and targeted internship activity through }\end{array}$ \\
\hline
\end{tabular}




\begin{tabular}{|l|l|}
\hline & $\begin{array}{l}\text { courses in technical-sports, biomedical, pedagogical, computer and linguistic } \\
\text { disciplines. }\end{array}$ \\
\hline & $\begin{array}{l}\text { The course aims to train graduates to design, coordinate and conduct physical and } \\
\text { athletic preparation activities in various team and individual sports, including } \\
\text { competitive sports activities for people with disabilities, using physical exercise and } \\
\text { training as a tool to prepare for sports activities, while maintaining a specific focus } \\
\text { on the educational dimension of promoting individual health and well-being. These } \\
\text { objectives are achieved, after a first group of common teachings, in the training } \\
\text { path divided into two curricula. The two courses are aimed at a specialist } \\
\text { and physical } \\
\text { performance } \\
\text { sciences }\end{array}$ \\
$\begin{array}{l}\text { deepening but also at the acquisition of knowledge and methodologies: - the } \\
\text { techniques and theories of training in the various contexts of sports practice; - the } \\
\text { methods and techniques of motor and sports activities for different sports in } \\
\text { different contexts both sports and gender and age classes; - the methods and } \\
\text { instrumentation of functional evaluation aimed at sports performance, including in } \\
\text { natural environments and mountains; - the techniques and methodologies related } \\
\text { to physical preparation for different sports activities carried out both individually } \\
\text { and as a team, indoor and outdoor. The course also includes an internship at } \\
\text { qualified external institutions and in structures and laboratories connected to the } \\
\text { University where to consolidate skills with direct experience in the professional } \\
\text { field. }\end{array}$ \\
\hline
\end{tabular}

Table 3. Profile jobs of Italian master program

\begin{tabular}{|c|c|c|c|c|c|c|c|c|c|c|c|c|c|c|c|}
\hline$B$ & $F$ & $G$ & $L^{\prime}$ & M & $\mathrm{N}$ & $P$ & $P$ & $P$ & $\mathrm{R}$ & $\mathrm{R}$ & $S$ & $\mathrm{~T}$ & $U$ & $U$ & \\
\hline 0 & I & $E$ & A & 1 & A & A & A & $E$ & 0 & 0 & $A$ & 0 & $D$ & $R$ & $E$ \\
\hline $\mathrm{L}$ & $R$ & $\mathrm{~N}$ & $Q$ & L & $P$ & $L$ & V & $\mathrm{R}$ & M & $\mathrm{M}$ & $\mathrm{L}$ & $\mathrm{R}$ & I & B & \\
\hline 0 & $E$ & 0 & $U$ & $A$ & 0 & $E$ & 1 & $U$ & A & $A$ & $E$ & 1 & $\mathrm{~N}$ & I & \\
\hline$G$ & $\mathrm{~N}$ & V & I & $\mathrm{N}$ & L & $\mathrm{R}$ & $A$ & $G$ & & & $n$ & $\mathrm{~N}$ & $E$ & $\mathrm{~N}$ & N \\
\hline $\mathrm{N}$ & Z & $A$ & $\mathrm{~L}$ & 0 & I & $M$ & & 1 & F. & T. & $\mathrm{N}$ & 0 & & 0 & \\
\hline
\end{tabular}

Nature and sports

guides

(3.4.1.5.1)

Instructors of non-

competitive sports $\quad \begin{array}{lllll}\nabla & \nabla & \square & \nabla & \nabla\end{array}$

$\square$

disciplines

(3.4.2.4.0)

Event and sports

facilities

$\nabla \quad \nabla$

$\nabla \quad \nabla \quad \nabla$

$\nabla$

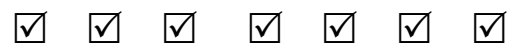

organizers

(3.4.2.5.1)

Sports observers

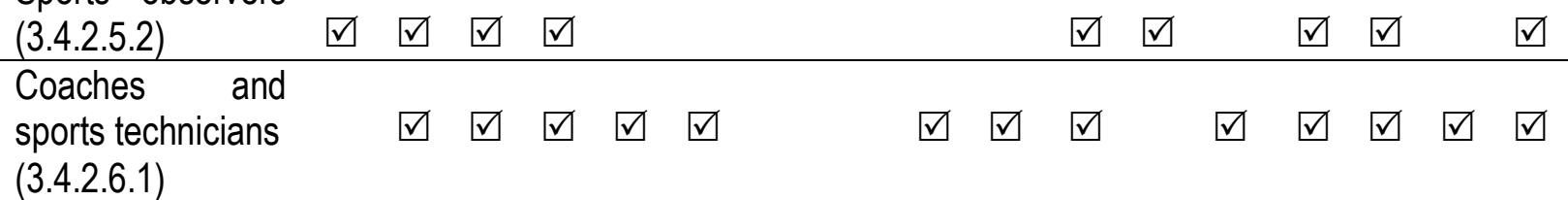




$\begin{aligned} & \text { Referees and } \\ & \text { competition }\end{aligned}$
judges (3.4.2.6.2)

\section{DISCUSSION}

The results, among each degree course of every university, are heterogeneous, certainly due to the total university autonomy that currently exists. In this heterogeneity the basis is biomedical in almost whole university.

\section{CONCLUSION}

This variety, if not disagreement, among the same degree courses of the different universities, does not help cooperation, despite the current laws on the subject prescribe obligations that, instead, should bring out the uniformity. In sport, as is well known, there is a growing awareness that cognitive-perceptive skills, such as anticipation, decision-making and situational awareness, are prerequisites for excellent performance. The activity of the body, assumed as a complex system, is characterized by a significant reduction of any predetermined complexity and, in a form compatible with individual needs, by situational awareness (Di Tore et al, 2018). These concepts should be used as a basis for the development of a single course of study for all and adapted to the full development of the qualities of the individual. Therefore, appropriate and necessary coordination actions are considered to make the training on the national field more uniform than the one currently in force. 


\section{REFERENCES}

Cassese, F.P., Raiola, G. (2017) The importance of sport in disability management, Sport Science, 10, pp. 7-11.

Ceciliani, A. (2018) From the embodied cognition to the embodied education in the physical and sports sciences, Encyclopaideia, 22 (51), pp. 11-24.

Ceciliani, A., Di Carlo, M., Tentoni, C. (2005) Mental process learning Medicina dello Sport, 58 (1), pp. 43-52.

D'Elia, F. (2019). The training of physical education teacher in primary school. Journal of Human Sport and Exercise, 14(1proc), S100-S104. https://doi.org/10.14198//hse.2019.14.Proc1.12

D'Elia, F., Mazzeo, F., Raiola, G. (2018) The core curriculum in the university training of the teacher of physical education in Italy, Journal of Human Sport and Exercise, 13, pp. S413-S420. https://doi.org/10.14198/ihse.2018.13.proc2.25

Di Tore, A.P., Raiola, G., D'Isanto, T. (2018) Situation awareness in sports science: Beyond the cognitive paradigm, Sport Science, 11 (1), pp. 44-48.

Di Tore, P.A., Schiavo, R., D'Isanto, T. (2016) Physical education, motor control and motor learning: Theoretical paradigms and teaching practices from kindergarten to high school, Journal of Physical Education and Sport, 16 (4), art. no. 205, pp. 1293-1297.

D'Isanto, T. (2016) Pedagogical value of the body and physical activity in childhood, Sport Science, 9, pp. 13-18.

D'isanto, T. (2019) Physical and sport education between Italian academic system and European Research Council structure panel, Journal of Human Sport and Exercise, 14, pp. S66-S76. https://doi.org/10.14198/ihse.2019.14.proc1.08

Gaetano, A. (2016) Relationship between physical inactivity and effects on individual health status, Journal of Physical Education and Sport, 16, pp. 1069-1074.

Pisapia, F., D'Isanto, T. (2018) Inclusive methods of adaptive training in sprints: A theoretical preliminary study, Journal of Physical Education and Sport, 18, art. no. 316, pp. 2101-2105.

Raiola, G., D'elia, F., Altavilla, G. (2018) Physical activity and sports sciences between European Research Council and academic disciplines in Italy, Journal of Human Sport and Exercise, 13, pp. S283-S295. https://doi.org/10.14198/hse.2018.13.proc2.13

Raiola, G. (2017) Motor learning and teaching method, Journal of Physical Education and Sport, 17, art. no. 236, pp. 2239-2243.

Raiola, G., Di Tore, P.A. (2017) Motor learning in sports science: Different theoretical frameworks for different teaching methods, Sport Science, 10, pp. 50-56.

Raiola, G. (2015a) Inclusion in sport dance and self perception Sport Science, 8, pp. 99-102.

Raiola, G. (2015b). Sport skills and mental health. Journal of Human Sport and Exercise, 10 (Specialissue), pp. S369-S376. https://doi.org/10.14198/hhse.2015.10.Proc1.27

Raiola, G. (2013) Body knowledge and motor skills, Knowledge Cultures, 1 (6), pp. 64-72.

Sanseviero, I., Cassese, F.P., Fonzo, E., Altavilla, G., D'elia, F. (2019) Study on the master's degree in sciences of sports evaluation and sport for disabled at the University of Salerno, Italy - Journal of Human Sport and Exercise, 14 (Proc2), pp. S239-S244. https://doi.org/10.14198/ihse.2019.14.proc2.12

Tiziana, D., Antonetta, M., Gaetano, A. (2017) Health and physical activity, Sport Science, 10 (1), pp. 100-105.

Valentini, M., Bernardini, C., Beretta, A., Raiola, G. (2018a) Movement and language development as an early childhood twin strategy: A systematic review, Sport Mont, 16 (3), pp. 107-112. https://doi.org/10.26773/smi.181019 
Valentini, M., Riccardi, F., Raiola, G., Federici, A. (2018b) Educational research: Motor area and relational area during children's personality development, Journal of Physical Education and Sport, 18, art. no. 327, pp. 2157-2174.

\section{(c)}

This work is licensed under a Attribution-NonCommercial-NoDerivatives 4.0 International (CC BY-NC-ND 4.0). 